\title{
Krónikus myeloid leukaemiás betegek követése a Marosvásárhelyi Hematológiai és Csontvelő-átültetési Klinika beteganyagában 2008 és 2018 között
}

\author{
Tunyogi Aliz-Beáta dr. ${ }^{1}$ - Lázár Erzsébet dr. ${ }^{2}$ - Benedek István dr. jr. ${ }^{2}$ \\ Sándor-Kéri Johanna ${ }^{2}$ - Zsigmond Annamária dr. ${ }^{2}$ - Benedek István dr. ${ }^{2}$ \\ 'TOPMED orvosi rendelő, Marosvásárhely, Románia \\ ${ }^{2}$ Marosvásárhelyi Orvosi és Gyógyszerészeti Egyetem, Hematológiai és Csontvelő-átültetési Klinika, Románia
}

\begin{abstract}
Bevezetés és célkitüzés: A krónikus myeloid leukaemia klonális myeloproliferativ megbetegedés; molekuláris alapját a BCR-ABL génátrendeződés jelenti, ami a 9-es és a 22-es kromoszóma transzlokációja miatt jön létre. A tirozinkinázgátlók jelentették az első célzott kezelést a BCR-ABL kinázaktivitásának gátlására. A betegek monitorizálására használt molekuláris módszerek, amelyek a BCR-ABL transzkriptek mennyiségi mérését célozzák, elengedhetetlenné váltak a betegség diagnózisában, illetve a terápiás válasz követésében.

Módszer: A Marosvásárhelyi Hematológiai és Csontveló-átültetési Klinikán vizsgáltuk a krónikus myeloid leukaemiával diagnosztizált betegeket 2008 és 2018 között.

Eredmények: Klinikánkon 59 beteg került követésre, az átlagéletkor 45 év volt, a férfi : nő arány 1,5: 1 . A betegek $80 \%$-a krónikus fázisban volt. A Sokal-indexe $61 \%$-nak alacsony, 27\%-nak közepes, 12\%-nak magas volt. Az átlagos követési idő 5 év és 9 hónap volt. 35 beteg molekuláris remissziót ért el átlag 11 hónappal a kezelés megkezdése után. Az 5 éves átlagos túlélés $80 \%, 10$ évre $76 \%$. A betegség fázisára lebontva a túléléseket 5 évre szignifikáns különbségeket találunk $(98 \%, 85 \%, 20 \%)$. Ha a Sokal-indexet vizsgáljuk, az 5 éves túlélés függvényében 91\%, 66\%, $51 \%$. A progressziómentes túlélés 5 évre $75 \%, 10$ évre $50 \%$. A Sokal-index függvényében az alacsony rizikójú betegek csupán 8\%-a, míg a magas rizikócsoportba tartozók 77\%-a progrediál. Az átlagos esély arra, hogy megmaradjon a molekuláris válasz, 5 évre $100 \%, 10$ évre $91 \%$, míg 15 évre csupán $52 \%$.

Következtetés: A növekvő BCR-ABL transzkriptszintek korai jelzői a terápiás válasz elvesztésének; ezáltal sikerült azonosítani azokat a betegeket, akiknek a kezelési stratégiáját újra kell értékelni.
\end{abstract}

Orv Hetil. 2019; 160(2): 67-72.

Kulcsszavak: krónikus myeloid leukaemia, BCR-ABL monitorizálás

Monitoring the chronic myeloid leukemia patients between 2008 and 2018; the experience of the Hematology and Bone Marrow Transplantation Unit Târgu-Mureș

Introduction and aim: Chronic myeloid leukemia is a clonal myeloproliferative disorder characterized by the BCR$\mathrm{ABL}$ gene rearrangement with translocation between chromosomes 9 and 22. The constitutively active BCR-ABL tyrosine kinase inhibitor became the standard frontline therapy. The molecular monitoring is essential.

Method: We studied the chronic myeloid leukemia patients at the Clinical Hematology and Bone Marrow Transplant Unit Tg-Mures between 2008 and 2018.

Results: We followed 59 patients, median age of 45 years, female : male ratio $1.5: 1.80 \%$ of the patients were in chronic phase. Sokal score was low in $61 \%$, intermediate $27 \%$ and high in $12 \%$ of the patients. The median follow-up time was 5 years and 9 months. 59\% of the patients reached molecular remission (average time 11 months). The cumulative overall survival was $80 \%$ at 5 years and $76 \%$ at 10 years. The overall survival according to disease phase was $98 \%, 85 \%, 20 \%$; according to Sokal score it was $91 \%, 66 \%, 51 \%$. The cumulative progression-free survival was $75 \%$ at 5 years and $50 \%$ at 10 years. Only $8 \%$ of the low risk patients are progressing opposite to $77 \%$ of the high risk patients. The cumulative probability to maintain the molecular remission for 5 years is $100 \%$, for 10 years $91 \%$ and for 15 years $52 \%$. 
Conclusion: A rising level of BCR-ABL is an early indication of the loss of response identifying the patients who need close monitoring and therapeutic change.

Keywords: chronic myeloid leukemia, BCR-ABL monitoring

Tunyogi A-B, Lázár E, Benedek I Jr, Sándor-Kéri J, Zsigmond A, Benedek I. [Monitoring the chronic myeloid leukemia patients between 2008 and 2018; the experience of the Hematology and Bone Marrow Transplantation Unit Târgu-Mureș]. Orv Hetil. 2019; 160(2): 67-72.

(Beérkezett: 2018. július 15.; elfogadva: 2018. augusztus 19.)

\begin{abstract}
Rövidítések
$\mathrm{AF}=$ akcelerált fázis; allo-HSCT $=$ (allogeneic hematopoietic stem cells transplantation) allogén haematopoeticus őssejtek átültetése; $\mathrm{BT}=$ blasztos transzformáció; $\mathrm{CCA}=$ (clonal cytogenetic abnormality) klonális citogenetikai eltérés; CF = (chronic phase) krónikus fázis; $\mathrm{CHR}=$ (complete hematologic response) komplett hematológiai válasz; $\mathrm{CML}=$ (chronic myeloid leukemia) krónikus myeloid leukaemia; DLI $=$ donorlymphocyta-infúzió; EBMT $=($ European Society for Bone Marrow Transplantation) Európai Csontvelő-transzplantációs Társaság; ELN = (European Leukemia Net) Európai Leukaemia Hálózat; GVHD = (graft-versus-host disease) graft versus host betegség; HLA = humán leukocytaantigén; IS = (international standard) nemzetközi standard; $\mathrm{MMR}=\left(\right.$ major molecu${ }^{-}$ lar remission) major molekuláris remisszió; $\mathrm{MR}=$ (molecular remission) molekuláris remisszió; PFS $=$ (progression-free survival) progressziómentes túlélés; $\mathrm{Ph}=$ Philadelphia; $\mathrm{RQ}-\mathrm{PCR}=$ (real-time quantitative polymerase chain reaction) valós idejü kvantitatív polimeráz-láncreakció; TKI = (tyrosine kinase inhibitor) tirozinkináz-gátló
\end{abstract}

A krónikus myeloid leukaemia (CML) klonális myeloproliferativ megbetegedés, amely az őssejteket érinti [ 1 , 2]. A betegség molekuláris alapja a BCR-ABL fúziós génátrendeződés [3], amely a 9-es és a 22-es kromoszóma reciprok transzlokációja miatt jön létre [4]. A kromoszómatörés egy adott génen belül különböző helyeken történhet meg, ennek fügvényében megkülönböztetünk major, minor és mikro-BCR-ABL gént, amely az átíródott onkoprotein nagyságát tekintve $210 \mathrm{kD}$ $\left(\mathrm{p} 210^{\mathrm{Bcr} / \mathrm{Abl}}\right), 190 \mathrm{kD}\left(\mathrm{p} 190^{\mathrm{Bcr} / \mathrm{Abl}}\right)$, illetve ritkábban 230 $\mathrm{kD}\left(\mathrm{p} 230^{\mathrm{Bcr} / \mathrm{Abl}}\right)$. Az átíródott onkoprotein fokozott tirozinkináz-aktivitással rendelkezik, ami a sejtosztódást és -differenciálódást szabályozva létrehozza a transzformációt [5]. Az imatinib (STI571), egy kis molekulájú tirozinkináz-gátló (TKI) jelentette az első célzott kezelést a konstitucionálisan aktív BCR-ABL kinázaktivitásának gátlására, és a TKI hamar a CML alapvonalbeli kezelésévé vált [6]. Az új terápiás lehetőségekkel a túlélés jelentősen megnőtt. A betegek monitorizálására használt molekuláris módszerek, amelyek a BCR-ABL transzkriptek mennyiségi mérését célozzák, elengedhetetlenné váltak a betegség diagnózisában, a magas rizikójú betegek azonosításában, illetve a terápiás válasz követésében. A valós idejü kvantitatív polimeráz-láncreakcióval (RQ-PCR) mért transzkriptmennyiség korrelációt mutat a maradék leukaemiás sejtek mennyiségével és a túléléssel [7]. Ha 3 hónappal a kezelés után nincs hematológiai válasz (CHR), a 6 hónapos kontrollnál a Philadelphia $(\mathrm{Ph})^{+}-$ metafázisok aránya meghaladja a 96\%-ot, vagy 12 hónap után a $>35 \% \mathrm{Ph}^{+}$terápiás kudarcnak minősül. 18 hónap után a megszerzett molekuláris válasz elvesztése, a BCRABL transzkriptek 1 loggal való növekedése, illetve új klonális citogenetikai eltérések (CCA) megjelenése jelenti a terápiás kudarcot. A magas kockázatú betegek kiszúrése nagyon fontos, mert ezek a betegek szorosabb követést igényelnek, hogy időben történő kezelési stratégiaváltással megakadályozzuk a betegség progresszióját [8].

\section{Módszer}

A Marosvásárhelyi Hematológiai és Csontvelő-átültetési Klinikán 2008 és 2018 között tanulmányoztuk a krónikus myeloid leukaemiával diagnosztizált betegeket. Öszszesen 59 beteget követtünk. A betegek rendszeres molekuláris monitorizálásban részesültek RQ-PCR-val. A diagnózis megállapításakor, illetve akcelerált fázisban citogenetikai vizsgálatot végeztünk. Növekvő transzkriptértékeket mutató betegeknél T351I- és M351T-mutációs analízisek elvégzésére volt lehetőségünk. Megtörtént a betegek rizikócsoportba való besorolása a Sokal-index kiszámításával. Az előrehaladott fázisban lévő betegeknél áramlásos citometriát végeztünk, meghatározva a blasztok arányát és fenotípusát.

A statisztikai adatfeldolgozást a Medcalc statisztikai szoftver (MedCalc Software, Ostend, Belgium) programjával végeztük.

\section{Eredmények}

Klinikánkon 59 beteg került követésre, az átlagéletkor 45 év volt ( 17 és 77 között); a férfi : nő arány $1,5: 1$ volt. A betegek nem és életkor szerinti megoszlását az 1 . ábra szemlélteti.

A diagnóziskor a betegek $80 \%$-a krónikus fázisban $(\mathrm{CF}), 12 \%$-a akcelerált fázisban $(\mathrm{AF})$ és $8 \%$-a blasztos transzformációban (BT) volt. A blasztos transzformációban elvégzett áramlásos citometria minden esetben akut myeloid leukaemiás transzformációt mutatott. 


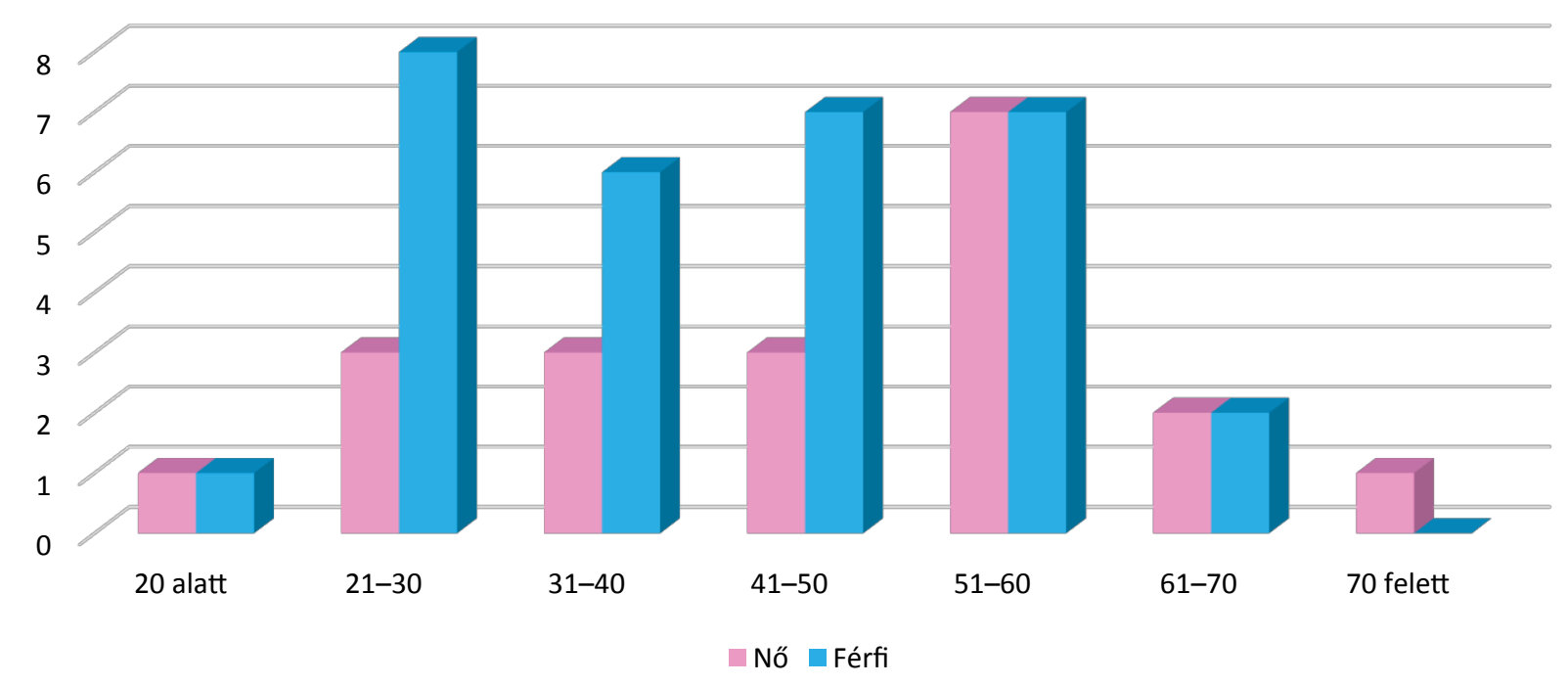

1. ábra | A betegek nemek és életkor szerinti megoszlása

A Sokal-indexe 61\%-nak alacsony volt, 27\%-nak közepes, $12 \%$-nak magas.

A magas sejtszámmal rendelkező betegeknél hidroxiureakezelést alkalmaztunk. Az esetek 95\%-ánál az imatinib volt az első vonalbeli kezelés. Hárman interferonkezelésben részesültek mint első vonalbeli terápia: két beteg, aki az imatinib bevezetése előtt került diagnosztizálásra, és egy fiatal hölgy, aki terhességének 17. hetében került hematológiai kivizsgálásra, és az imatinib kontraindikált volt.

$\mathrm{Az}$ átlagos követési idő 5 év és 9 hónap volt (egy hónap és 15 év között). 35 beteg ért el molekuláris remiszsziót (MR) átlag 11 hónappal a kezelés megkezdése után. A molekuláris remisszió fokának megoszlását tekintve: 5/35 MR3 (BCR-ABL <0,1\% IS), 18/35 MR4 (BCR-ABL $<0,01 \%$ IS), $7 / 35$ MR4,5 (BCR-ABL $<0,003 \%$ IS) és $5 / 35$ MR5 nem detektálható BCR-ABL szintekkel. A MR-ban lévő betegek 85\%-a krónikus, míg $15 \%$-a akcelerált fázisban volt a diagnózis megállapításakor.

Hat esetben észleltük a remisszió elvesztését. A molekuláris válasz elvesztése átlagosan 5 évvel a kezelés megkezdése után következett be. Ezek közül négy beteg a második vonalbeli TKI-nak köszönhetően újra MR-ban van. A második MR-ig eltelt idő azonban hosszabb, átlagosan 33 hónap.

Növekvő BCR-ABL transzkriptértékeket 19 esetben észleltünk. Ezeknél a pácienseknél T351I- és M351Tmutációs analízis elvégzésére volt lehetőség. Hat esetben pozitív volt az M351T-mutáció, amely rezisztenciát mutat az imatinibre. A növekvő transzkriptekkel rendelkező betegeknél második, illetve két esetben harmadik generációs TKI-t vezettünk be.

Az 5 éves átlagos túlélés 80\%, 10 évre 76\%. A betegség fázisára lebontva a túléléseket 5 évre szignifikáns különbségeket találtunk (logrank teszt $[\mathrm{p}=0,0001]$ ) a krónikus fázisban $(90 \%)$, az akcelerált fázisban $(85 \%)$ és a blasztos transzformációban (20\%) lévő betegek között. A 10 éves túlélés a krónikus fázisban 90\%, az akcelerált fázisban $55 \%$ (2. ábra).

A Sokal-index függvényében vizsgálva az 5 éves túlélést az alacsony kockázatúak 91\%-a, míg a magas rizikóval rendelkezóknek csupán az 51\%-a van életben (logrank teszt $[\mathrm{p}=0,0029])$ (3. ábra).

$\mathrm{Az} 5$ és 10 éves átlagos progressziómentes túlélés (PFS) $75 \%$, illetve $50 \%$. Ha a Sokal-index függvényében vizsgáljuk a progressziómentes túlélést, az alacsony kockázatúaknál 92\%, míg a magas rizikócsoportúaknál 22\% (4. ábra).

A kumulatív esélye annak, hogy a beteg megtartsa elözetesen megszerzett MR-ját, 5 évre 100\%, 10 évre 91\%, míg 15 évre csupán $52 \%$ (5. ábra).

Hét esetben végeztünk allogén csontvelö-átültetést (allo-HSCT). A nemek szerinti megoszlást tekinve 4 volt férfi, és 3 nő. Az átlagéletkor 37 év volt (24 és 47 között). Két fiatal (24, illetve 26 éves), akik krónikus fázisban voltak, és intoleranciát mutattak a TKI-kezelésre, il-

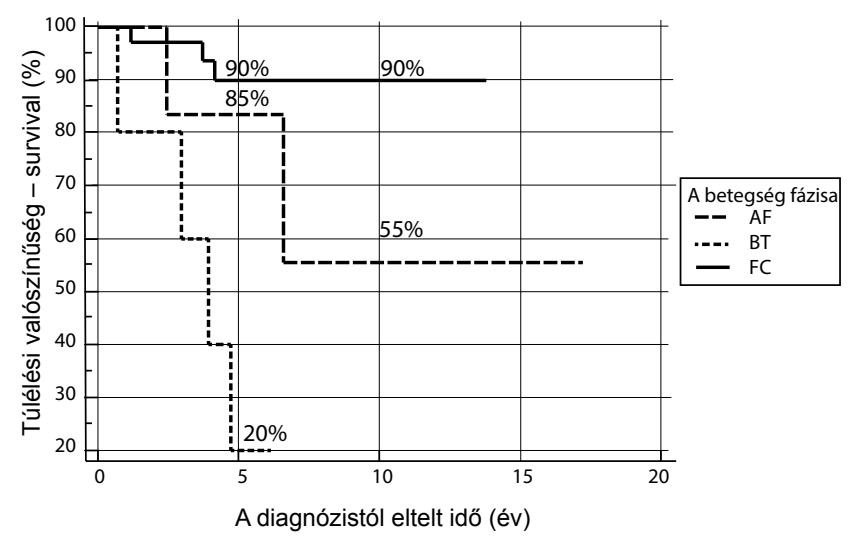

\begin{tabular}{l|l} 
2. ábra & $\begin{array}{l}\text { A betegek túlélése a betegség fázisainak függvényében } \\
\mathrm{AF}=\text { akcelerált fázis; } \mathrm{BT}=\text { blasztos transzformáció; } \mathrm{CF}=\mathrm{króni} \text { - } \\
\text { kus fázis } \\
\text { Logrank-teszt }(\mathrm{p}=0,0001)\end{array}$
\end{tabular} 


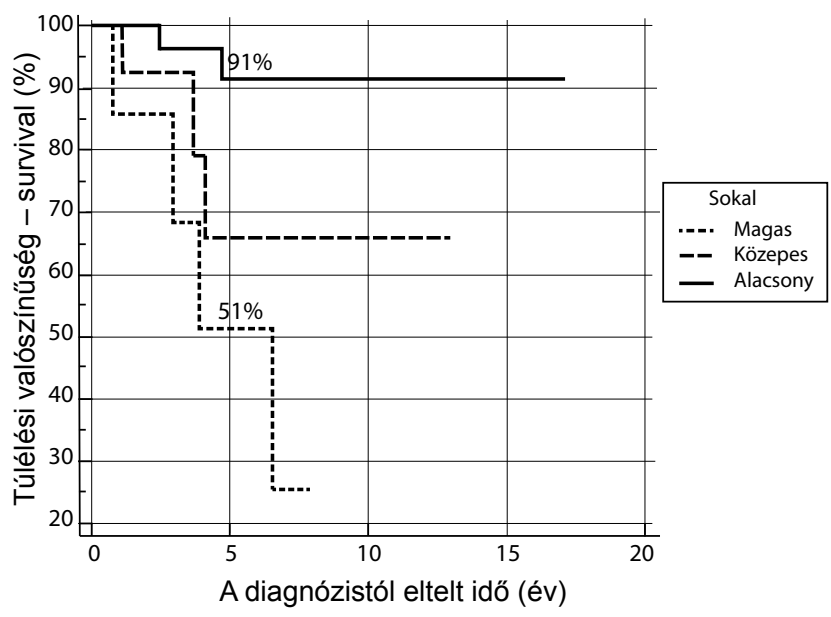

3. ábra

A betegek túlélése a Sokal-index függvényében

Logrank-teszt $(\mathrm{p}=0,0029)$

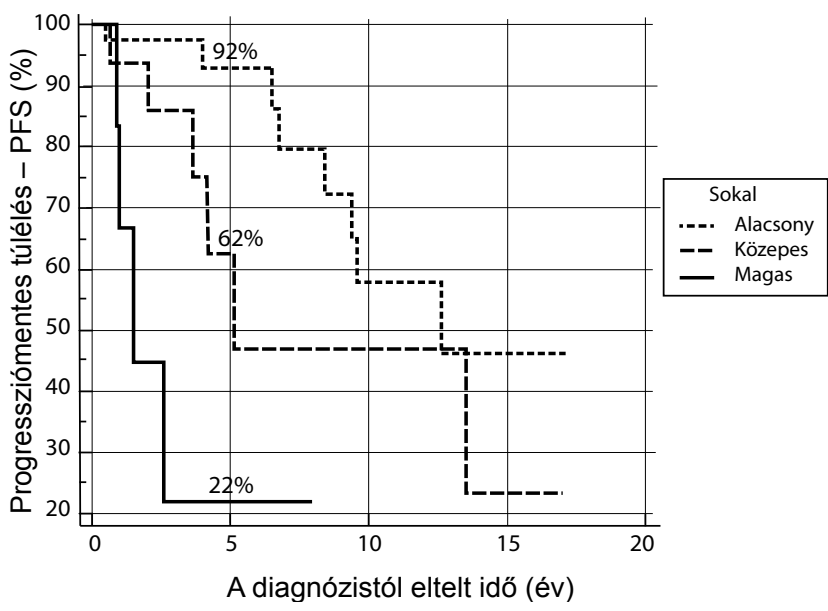

4. ábra

$\mid \begin{aligned} & \text { A progressziómentes túlélés a Sokal-index függvényében } \\ & \text { Logrank-teszt }(\mathrm{p}<0,0001)\end{aligned}$

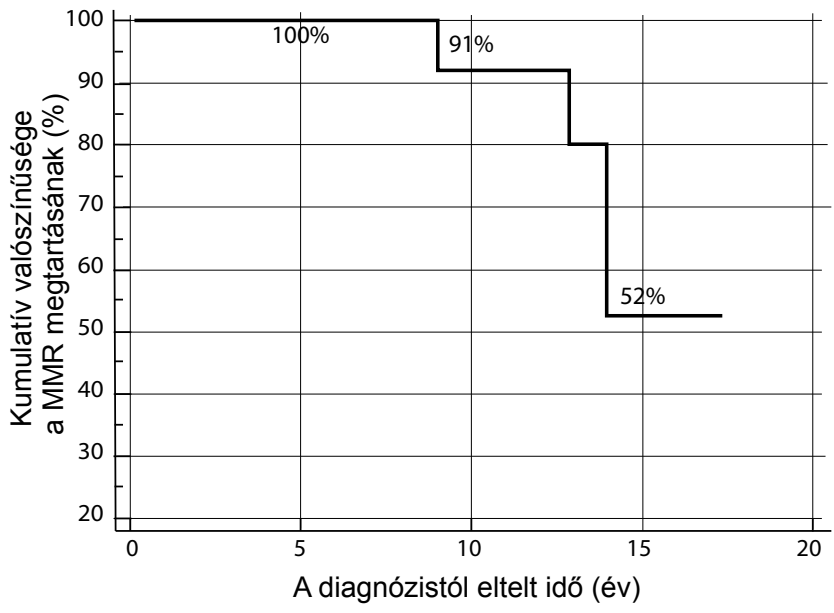

5. ábra

A kumulatív esélye annak, hogy a beteg megtartsa molekuláris válaszát TKI-kezelés alatt

letve 5 beteg progresszió miatt került transzplantációra (3 AF és 2 BT). A donorok 100\%-os HLA-kompatibilitást mutató családi donorok voltak. A TKI-intoleranciát mutató betegek alacsony rizikójú EBMT-pontszámmal rendelkeztek. Mindkettő teljes molekuláris remisszióban van 12 évvel, illetve 8 hónappal a transzplantáció után. A progresszió miatt transzplantációra került betegek magas EBMT-pontszámmal rendelkeztek. Egyikük korai viszszaesést és progressziót mutatott; az immunszuppresszió visszavonása után donorlymphocyta-infúzióban (DLI) részesült, majd kemoterápiás kezelésben - 1 évvel a transzplantáció után progresszió miatt elhalálozott. Teljes molekuláris remisszióban súlyos fertőzéses szövődmények miatt 3 beteg meghalt 3,6, illetve 7 hónappal a traszplantáció után. Az utolsó esetben 5 éves teljes MR után súlyos krónikus graft versus host betegség (GVHD) alakult ki, amely nem reagált a kezelésre.

\section{Megbeszélés}

Beteganyagunkban az átlagéletkor 45 év volt, ami jóval alacsonyabb, mint az európai nagyobb összefoglaló tanulmányokban közölt átlag (60-65 év), a betegek nemek szerinti megoszlása viszont azonos [9].

A krónikus myeloid leukaemiás betegek az új TKI-kezeléseknek köszönhetően a hosszú távú túlélést illetően jó prognózissal rendelkeznek. Az 5 éves progressziómentes túlélés 85-95\%, és az 5 éves átlagos túlélés 8595\% [10]. A mi betegeinknél az 5 éves PFS 75\%, míg az átlagos túlélés 5 évre 80\%. Egyik magyarázata lehet ennek a különbségnek, hogy a diagnózistól a TKI bevezetéséig eltelt idő hoszabb volt 2008 és 2017 között. Ha lebontjuk az adatokat a Sokal-index függvényében, az 5 éves PFS az alacsony rizikócsoportban 92\%, míg a magas rizikócsoportban $22 \%$.

A molekuláris monitorizálási módszerek hatékonyságának növekedésével egyre jobban lehet követni a kezelésre adott választ. A módszer előnye, hogy a perifériás vérből is elvégezhető, és a mért transzkriptszintek jó öszszefüggést mutatnak a leukaemiás sejtmennyiséggel [11]. A nemzetközi standard (IS) bevezetésével a laborok közti mérési különbségek eltüntek [12].

A kezelés elsődleges célja a MMR elérése. A mi betegeink 59\%-a érte el 11 hónap alatt a MR-átlagot, és a betegek $100 \%$-a megtartotta válaszát 5 évvel a kezelés megkezdése után, illetve 91\%-a 10 évvel a kezelés megkezdése után az első vonalbeli TKI-kezeléssel.

A szuboptimális válasszal rendelkező betegek korai azonosítása rendkívül fontos, a kezelés módosításával meggátolva a betegség transzformációját, bár az ELNajánlás a szuboptimális helyett inkább a „warning” megnevezést részesíti előnyben, gyakoribb molekuláris monitorizálást javasolva a kezelési stratégia eldöntésére [13]. A levett vérpróbák minőségi különbsége és a vizsgálati technika miatt mérésenként 0,5 log különbség is lehet. Az alacsony BCR-ABL transzkriptingadozások túlértékelése szükségtelen terápiás változtatásokhoz vezethet. A kezelés változtatását mindig alá kell támasztani egy második méréssel, amely konfirmálja a transzkriptnövekedést. A növekvő transzkriptszint vagy a molekulá- 
ris válasz elvesztése esetén kötelező a citogenetikai vizsgálat elvégzése az esetleges CCA kimutatására [14]. Növekvő transzkriptszintek esetén a mutációs analízis elvégzése a terápiás változtatás irányában ad nagy segítséget.

Növekvő transzkriptértékeket 19 betegnél észleltünk. Két mutáció elvégzésére volt lehetőség, ezek a T351I és az M351T. A T351I negatív volt minden esetben. Hat betegnél volt pozitív az M351T, amely rezisztenciát kölcsönöz imatinibre. A mutációs panel kiegészítése valószínúleg további BCR-ABL mutációk felderítésére adott volna lehetôséget.

A TKI-kezelés bevezetésével a transzplantáció indikációja megváltozott: rezisztencia vagy intolerancia második vonalbeli TKI-kezelésre, T351I-mutációval rendelkező betegek, akcelerált vagy blasztos transzformáció jelentik a major indikációt. Allogén transzplantáció után az 5 éves PFS krónikus fázisban 90\%, akcelerált fázisban 40-50\%, míg blasztos transzformációban csupán 10$20 \%$ [15]. Az allogén csontvelö-átültetéssel jó eredményeket értünk el a családi donorral rendelkező alacsony rizikójú fiatal betegeinknél, akik intoleranciát vagy rezisztenciát mutatnak a TKI-ra. Akcelerált vagy blasztos fázisban lévő idősebb betegeknél, akiknél magas az EBMT-pontszám, a túlélés esélye csökken [16]. Esetszámunk azonban kicsi a statisztikai adatfeldolgozáshoz vagy következtetések levonásához. A transzplantációk nagy része a második, illetve harmadik generációs TKI-k államilag támogatott elérhetősége előtt volt.

A növekvő transzkriptszintek esetén az esetleges donorok azonosítása fontos [17].

A termékeny korban lévő fiatal nőknél, akik gyereket szeretnének, fontos a TKI-kezelés megállítása, mivel ismert az első trimeszteri terhesség alatt adott imatinib, illetve daszatinib teratogén, illetve a nilotinib embryo- és fetotoxicus hatása [18]. Esetanyagunkban két fiatal nőnél, aki több mint 2 éve volt MR4-, illetve MR4,5-ben, kérésre megállítottuk az imatinibkezelést, mert gyereket szerettek volna. Az első esetben nem következett be a várt terhesség a lassan növekvő transzkriptértékek miatt, ezért a beteg a TKI-kezelés visszavezetése mellett döntött. A második esetben a páciens 3 hónappal a TKI megállítása után elvesztette molekuláris válaszát. Mindkét esetben megtörtént az első vonalbeli TKI visszavezetése. A második esetben a kezelés visszavezetése után csökkentek a transzkriptértékek, de a 6 hónapos kontrollnál már növekvő tendenciát mutattak. Mutációs analízist végeztünk, amely az M351T-mutáció jelenlétét igazolta, így a második generációs TKI bevezetése után 1 évvel ő újra MR-ba került. Harmadik betegünk egy terhességének 17. hetében lévő fiatal nő volt, aki a szülésig interferonkezelésben részesült, majd TKI-kezelést kapott.

Több tanulmány is vizsgálja a TKI-kezelés megállítását az alacsony vagy közepes kockázatú krónikus fázisban lévő betegeknél (STIM, ENESTFreedom). A kritériumok: minimum 5 év kezelés után, a major molekuláris remisszióba jutásig kevesebb mint 2 évnek kell eltelnie, legalább 2 év MR4,5 imatinibkezelés alatt. A betegek 61\%-a mutatott molekuláris visszaesést, és az események 95\%-a az első hét hónapban történt. A követési idő átlag 4 év volt. A nilotinib estén minimum 2 év kezelés, MR4,5 volt a kritérium. A betegek 48,4\%-ánál következett be molekuláris visszesés, bár a követési idő jóval rövidebb volt, mint az előző tanulmány esetén (majdnem 1 év-40 hét) [19, 20]. Eseteink vizsgálatakor kiderült, hogy annak esélye, hogy a beteg megtartsa molekuláris válaszát, 5 évre 100\%, 10 évre 91\%, míg 15 évre csupán $52 \%$. A betegek nagy része 5 év kezelés után veszti el major vagy teljes molekuláris válaszát addicionális mutációk vagy citogenetikai eltérések miatt. A kezelés megkezdése után 15 évvel a betegeknek csupán az 52\%-a van major vagy teljes molekuláris remisszióban. A TKI-kezelés megállításáig eltelt idő kiterjesztése, illetve a teljes molekuláris remisszió (MR5) mint kritérium bevezetése valószínúleg jobban azonosítaná azokat a betegeket, akik a TKI-kezelés leállítása után is megtartanák a teljes molekuláris remissziót.

Anyagi támogatás: A közlemény megírása, illetve a hozzá kapcsolódó kutatómunka anyagi támogatásban nem részesült.

Szerzôi munkamegosztás: T. A.-B., B. I. jr., S.-K. J., Zs. A.: Az adatok gyüjtése. T. A.-B.: Statisztikai adatfeldolgozás. A kézirat megírása. L. E., B. I.: A kézirat revíziója, jóváhagyása. A cikk végleges változatát valamennyi szerző elolvasta és jóváhagyta.

Érdekeltségek: A szerzőknek nincsenek érdekeltségeik.

\section{Irodalom}

[1] Arrigoni E, Del Re M, Galimberti S, et al. Concise review: chronic myeloid leukemia: stem cell niche and response to pharmacologic treatment. Stem Cells Transl Med. 2018; 7: 305-314.

[2] Copland M. Chronic myelogenous leukemia stem cells: what's new? Curr Hematol Malig Rep. 2009; 4: 66-73.

[3] Zhou F, Jin R, Hu Y, et al. A novel BCR-ABLI fusion gene with genetic heterogeneity indicates a good prognosis in chronic myeloid leukemia case. Mol Cytogenet. 2017; 10: 19.

[4] Luatti S, Baldazzi C, Marzocchi G, et al. Cryptic BCR-ABL fusion gene as variant rearrangement in chronic myeloid leukemia: molecular cytogenetic characterization and influence on TKIs therapy. Oncotarget 2017; 8: 29906-29913.

[5] Keramatinia A, Ahadi A, Akbari ME, et al. Genomic profiling of chronic myelogenous leukemia: basic and clinical approach. J Cancer Prev. 2017; 22: 74-81.

[6] Deininger MW. Milestones and monitoring in patients with CML treated with imatinib. Hematology Am Soc Hematol Educ Program 2008; 1: 419-426.

[7] Hughes T, Deininger M, Hochhaus A, et al. Monitoring CML patients responding to treatment with tyrosine kinase inhibitors: review and recommendations for harmonizing current methodology for detecting $B C R-A B L$ transcripts and kinase domain mutations and for expressing results. Blood 2006; 108: 28-37. 
[8] Hochhaus A, Saussele S, Rosti G, et al. Chronic myeloid leukaemia: ESMO Clinical Practice Guidelines for diagnosis, treatment and follow-up. Ann Oncol. 2017; 28(Suppl 4): iv4l-iv5l.

[9] Demeter J, Poros A, Bödör Cs, et al. Chronic myelogenous leukemia: diagnosis and treatment. [A krónikus myeloid leukaemia korszerú diagnosztikája és kezelése.] Orv Hetil. 2016; 157: 1459-1468. [Hungarian]

[10] Kantarjian H, O'Brien S, Jabbour E, et al. Improved survival in chronic myeloid leukemia since the introduction of imatinib therapy: a single-institution historical experience. Blood 2012; 119: 1981-1987.

[11] Branford S, Hughes TP, Rudzki Z. Monitoring chronic myeloid leukaemia therapy by real-time quantitative PCR in blood is a reliable alternative to bone marrow cytogenetics. Br J Haematol. 1999; 107: 587-599.

[12] Müller MC, Cross NC, Erben P, et al. Harmonization of molecular monitoring of CML therapy in Europe. Leukemia 2009; 23: 1957-1963

[13] Baccarani M, Deininger MW, Rosti G, et al. European Leukemia Net recommendations for the management of chronic myeloid leukemia: 2013. Blood 2013; 122: 872-884.

[14] Cortes J, Quintás-Cardama A, Hagop M, et al. Monitoring molecular response in chronic myeloid leukemia. Cancer 2011; 117: $1113-1122$.

[15] Gupta A, Khattry N. Current status of hematopoietic stem cell transplant in chronic myeloid leukemia. Indian J Med Paediatr Oncol. 2014; 35: 207-210
[16] Hemmati PG, Terwey TH, le Coutre P, et al. A modified EBMT risk score predicts the outcome of patients with acute myeloid leukemia receiving allogeneic stem cell transplants. Eur J Haematol. 2011; 86: 305-316.

[17] Apperley J, Carreras E, Gluckman E, et al. (eds.) ESH-EBMT Handbook on Haematopoietic Stem Cell Transplantation (2008 Revised Edition). 5th edn. Genoa, 2008.

[18] Abruzzese E, Trawinska MM, Perrotti AP, et al. Tyrosine kinase inhibitors and pregnancy. Mediterr J Hematol Infect Dis. 2014; 6: e2014028

[19] Mahon FX, Réa D, Guilhot J, et al. Discontinuation of imatinib in patients with chronic myeloid leukaemia who have maintained complete molecular remission for at least 2 years: the prospective, multicentre Stop Imatinib (STIM) trial. Lancet Oncol. 2010; 11: 1029-1035.

[20] Hochhaus A, Masszi T, Giles FJ, et al. Treatment-free remission following frontline nilotinib in patients with chronic myeloid leukemia in chronic phase: results from the ENESTfreedom study. Leukemia 2017; 31: 1525-1531.

(Lázár Erzsébet dr., Târgu Mureș, Str. Revoluției nr. 35, Jud. Mures, cod 540042 Romania e-mail: erzsebetlazarbenedek@gmail.com)

\title{
MEG HÍ Vó
}

\section{A Szent János Kórház és Észak-budai Egyesített Kórházak Tudományos Bizottsága} tisztelettel meghívja az érdeklődőket a következő tudományos ülésére.

\author{
Idöpont: 2019. január 24. (csütörtök) 14 óra
}

Helyszín: Szent János Kórház Auditóriuma - 1125 Budapest, Diós árok 1-3.

Téma: Újdonságok a kardiológiában (anticoaguláns kezelés, myocardialis infarctus)

(III. Belgyógyászati-Kardiológiai Osztály)

Üléselnök: Prof. Dr. Jánosi András

\section{Előadások}

Dr. Kazinczy Rita: NOAC kezelés pitvarfibrillációban és vénás thromboemboliás kórképekben

Dr. Stadler Péter: NOAC kezelés speciális helyzetekben

20 perc

Dr. Radics Péter: Myocardialis infarctus definícója a 2018-as ESC guideline szerint

15 perc

Minden érdeklődőt szeretettel várunk! 